\title{
Characterization of Dust Produced from Burning a Mixture of Tar and Heavy Oil ${ }^{*}$
}

\author{
by James M. FILIO ${ }^{1}$, Hun S. CHUNG ${ }^{2}$, Yoshiaki UMETSU ${ }^{3}$ \\ and Fumio SAITO ${ }^{4}$
}

\begin{abstract}
Characteristics of electrostatic precipitator dust (EP dust) in an oil-fired power station was investigated using chemical analysis, SEM-EDX, X-ray diffraction and fluorescence, TG-DTA and sieve analyses. About $93.5 \%$ of the dust is combustible, composed mainly of ammonium sulfate and carbon. The remaining $6.5 \%$ is non-combustible compounds containing some valuable metals such as vanadium, nickel, magnesium, molybdenum, copper, cobalt, and gallium. The carbon particles are mostly spherical in shape and riddle with holes. Ammonium sulfate is formed after the addition of aqueous ammonia to prevent acid smut due to SOx gases and is observed to be coating the particles of uncombusted carbon and metal stuffs. Furthermore, the ammonium sulfate reacts with the metals to form metal sulfates and ammonium metal sulfate complexes. Dissolution test using distilled water, without adding any promoters, reveals that Ni $90 \%, \mathrm{Fe} 75 \%$ and V $10 \%$ are extracted from the dust. Leaching of screened specimens shows that more nickel compounds dissolve from the finer grained samples while more vanadium compounds dissolve from coarser grained ones. Dry grinding of the dust using a tumbling ball mill gives us the increase in solubility of vanadium compounds in water with the progress of grinding.
\end{abstract}

KEY WORDS : Grinding, Leaching, EP Dust, Vanadium, Nickel, Iron, Carbon, Ammonium Sulfate

\section{Introduction}

The Kashima Kita power plant uses orimulsion-oil-mixture as fuel in their boilers. The orimulsion fuel used is derived from natural tar deposits originating from Orinoco, Venezuela. This type of fuel has a high sulfur content and produces considerable amounts of solid particles after combustion. These solid particles are composed of mainly a) small quantities of ash accumulating on the boiler tubes and in the bottom of the furnaces and, b) large quantities of dust, which would be conveyed out in the flue gases unless harmless process is considered. The former particles are collected in small amounts once or twice a year. The latter ones are collected by electrostatic precipitators which yield a total of about 5,000 tons per year. The dust is used to describe the flue particles because it contains carbon and small amounts of metal compounds.

$\mathrm{NO}_{x}$ emission in the plant is controlled by in-furnace $\mathrm{NO}_{x}$ removal process, low $\mathrm{NO}_{x}$ burner and over fire air methods. The flue emissions which contain environmentally harmful $\mathrm{SO}_{x}$ gases are treated with aqueous $\mathrm{NH}_{3}$ forming $\left(\mathrm{NH}_{4}\right)_{2} \mathrm{SO}_{4}$ then collected together with the unburnt carbon particles by

\footnotetext{
* Received February 17, 1994 : accepted for publication July 28, 1994

1. 3. 4. Institute for Advanced Materials Processing, Tohoku University, 2-1-1, Katahira, Aoba-ku, Sendai 980, Japan

2. Korea Institute of Geology, Mining and Materials, 30 Kajung-dong, Yusong-ku, Yaejon,Korea 305-350

1. Visiting Scientist, 2. Dr., 3. Associate Professor, Dr., 4. Professor, Dr.,
}

the electrostatic precipitators. This is hereafter called the electrostatic precipitator dust (EP dust). The remaining unreacted $\mathrm{SO}_{x}$ in the flue gas is further collected in the desulfurization $\mathrm{fa}$ cility as gypsum and sulfuric acid.

Since the EP dust contains heavy metal compounds and ammonium sulfate, strict pollution control regulations require the prior treatment of these solid wastes before disposal. A novel process was recently developed to recycle ammonia and collect some valuable products such as ammonium metavanadate, nickel hydroxide, magnesium hydroxide, gypsum and carbon from the EP dust ${ }^{1)}$.

However, recovery of valuable metals from the dust is still insufficient. Especially the yield of vanadium is quite low at around 10 percent. The improvement of vanadium yield has preliminary been endeavored with the aid of mechanical activation by grinding. The preliminary experiment on the EP dust suggests the improvement of vanadium yield. Though further experiment on the EP dust needs to clarify its characteristics, few studies were undertaken on the EP dust despite its peculiar nature although it was considered as waste material. In this regard, we tried to examine and characterize the $\mathrm{EP}$ dust and its metal contents using $\mathrm{X}$-ray diffraction and fluorescence, SEM-EDX (Energy Dispersive X-ray analysis), ICP, particle size analysis, TG-DTA and water leaching.

\section{Experimental}

a) Material

The EP dust sample was received from the Kashima Kita 


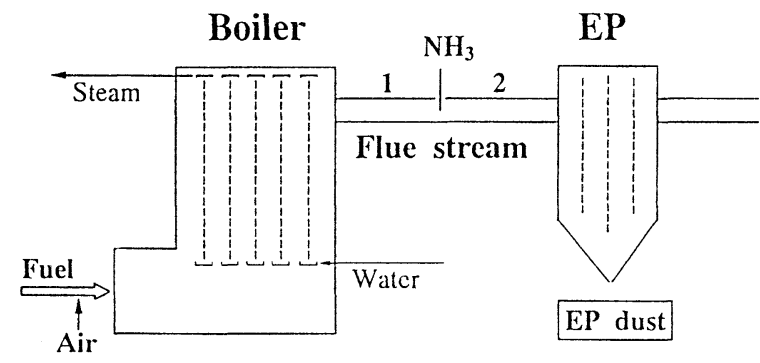

Fig. 1 Production and collection of EP dust.

power plant located at Kashima, Ibaraki Prefecture, Japan. The EP dust was produced from burning a mixture of Venezuelan orimulsion and Arabian heavy oil. It contained uncombusted carbon and metals which were transported out through the flue together with $\mathrm{SO}_{x}$ gases from the combustion chamber. Ammonia is injected in the flue to fixate corrosive $\mathrm{SO}_{x}$ gases resulting in the formation of ammonium sulfate. This compound is then collected together with other particles by the electrostatic precipitator. The production and collection of EP dust are outlined in Fig. 1. Generally, the composition of EP dust is significantly changing in daily plant operation depending on the oil combustion condition and the fuel fed ratio to the boilers. The sample used in this experiment was brought from the electrostatic precipitator operating under the fixed combustion conditions.

As received, the EP dust contained about $5 \%$ moisture. Using the pycnometer method, the density in toluene was determined to be $1.69 \mathrm{Mg} / \mathrm{m}^{3}$.

Combustible components of the sample such as carbon, hydrogen and nitrogen were quantitatively analyzed by a combustion thermal conductivity method using a Yanagimoto $\mathrm{CHN}$ corder. The amounts of $\mathrm{S}, \mathrm{V}, \mathrm{Ni}, \mathrm{Fe}, \mathrm{Mg}$ and ash were measured by a standard analytical method, as described in JIS M-8815.

$\mathrm{X}$-ray diffraction data were taken using $\mathrm{CuK} \alpha$ radiation. A singly-bent pyrolitic graphite monochromator (filter) was placed in the diffracted beam path. The sample was packed on a glass holder of $20 \mathrm{~mm} \times 18 \mathrm{~mm} \times 0.5 \mathrm{~mm}$. The heavy metal components in the sample were determined using $\mathrm{X}$-ray fluorescence analysis. The sample for fluorescence analysis was placed in an aluminum ring with a thickness of $5 \mathrm{~mm}$ and diameter of $35 \mathrm{~mm}$ and pressed at $100 \mathrm{kN}$. The characteristic spectrum of the metal components was taken using $\mathrm{Ru}$ target powered at $50 \mathrm{kV}$ and $50 \mathrm{~mA}$ and $\mathrm{LiF}$ detector. Thermogravimetric (TG) and differential thermal analyses (DTA) were simultaneously carried out in air at a heating rate of $10 \mathrm{~K} / \mathrm{min}$.

\section{b) Particle size distribution}

Particle size distribution was measured using a laser diffraction-based particle-size analyser (Malvern Master Sizer). The sample was dispersed in $10 \%$ ethanol solution for $3 \mathrm{~min}$ using an ultrasonic bath. The suspension was then placed in the analyzer's bath with ultrasonic disperser and stirred for 3 min before particle size distribution was measured. Carbon particles were detected by the analyzer because the ammonium sulfate and some metal compounds are soluble in water. A scanning electron microscope equipped with EDX unit was used to observe the EP dust and analyze its chemical composition. The SEM samples were mounted on carbon tape and coated with carbon and gold for EDX analysis and morphology observations, respectively.

c) Solubility

1) The EP dust suspension in distilled water was prepared at solid concentration of $5,10,15,20,25,30$, and 35 mass percent. The slurry was agitated using a magnetic stirrer for 1 hour. After the residue was filtered off with a filter paper (No. $5 \mathrm{C}$ ), the filtrate was analyzed for vanadium, nickel and iron by ICP.

2) The EP dust was screened using JIS Standard sieves of 100 (opening size, $149 \mu \mathrm{m}), 200(74 \mu \mathrm{m}), 300(46 \mu \mathrm{m})$ and 400 (37 $\mu \mathrm{m})$ mesh. Portions of the screened specimens were ground to pass 400 mesh to prepare the ground specimens using an agate mortar. Tumbling ball mill made of alumina with 2,000 $\mathrm{ml}$ inside volume was used for preliminary grinding of the EP dust sample. The inner diameter and length of the pot were $13 \mathrm{~cm}$ and $14 \mathrm{~cm}$, respectively. Zirconia balls of $5 \mathrm{~mm}$ diameter were charged into the pot at $40 \mathrm{vol} \%$ in ball filling. The pot was filled with $100 \mathrm{~g}$ of the sample, and milling up to 5,700 minutes under dry condition was carried out at the rotational speed of $180 \mathrm{rpm}$. About $3 \mathrm{~g}$ of ground specimen was taken for characterization. The screened and ground specimens were prepared in $5 \%$ solid concentration slurries. The slurry was kept standing under magnetic stirrer agitation for 1 hour, and then filtered. The filtrate was analyzed for vanadium, nickel and iron by ICP.

\section{Results and Discussion}

The results of chemical analysis of the EP dust sample, as received, are summarized in Table 1. The sample contained around $1.49 \% \mathrm{~V}, 0.57 \% \mathrm{Ni}$, and $0.23 \% \mathrm{Fe}$. Burriesci et $\mathrm{al}^{2)}$ reported that the EP ash samples from Italian power plants using Venezuelan fuel contain as high as $7.0 \%$ vanadium, 2.2 $\%$ nickel and $11.5 \%$ iron. Okuwaki et $\mathrm{al}^{3)}$ reported that the EP dust in Kashima power plant contains 1.9 to $3.1 \%$ vanadium, 0.5 to $0.8 \%$ nickel and 0.3 to $0.4 \%$ iron. The difference in metal content of the EP dust found in this study from that in Okuwaki's work is attributable to the variance in daily plant operations. In addition, as stated before, combustion conditions such as the boiler's firing operation, adjustment ratio of orimulsion to oil fuel mixture and the power generation demand affect the resulting consistency of the metal components of the EP dust. Generally, the composition of EP dust is significantly changing depending on the oil combustion condition and the fuel fed to the boilers.

Fig. 2 shows the X-ray fluorescence diffraction profile of heavy metal elements in the EP dust. The analysis of heavy

Table 1 Chemical composition of EP dust (mass \%)

\begin{tabular}{ccccccccc}
\hline $\mathrm{C}$ & $\mathrm{H}$ & $\mathrm{N}$ & $\mathrm{SO}_{4}$ & $\mathrm{~V}$ & $\mathrm{Ni}$ & $\mathrm{Fe}$ & $\mathrm{Mg}$ & ash \\
28.4 & 3.82 & 12.4 & 46.4 & 1.49 & 0.57 & 0.23 & 0.58 & 6.50
\end{tabular}




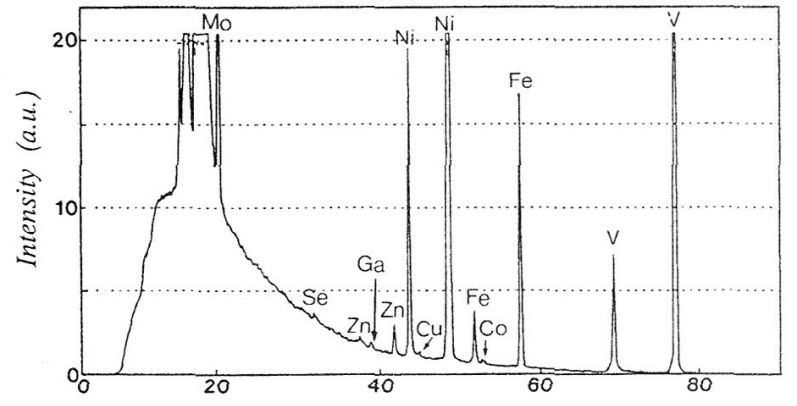

$2 \theta$ (Degree, Ru target)

Fig. 2 X-ray fluorescence profile of heavy metal elements in EP dust.

metals revealed the presence of vanadium, nickel, iron, molybdenum, zinc, copper, selenium, cobalt and gallium in the EP dust. X-ray diffraction of this sample was then taken to identify the metal compounds contained. The diffraction pattern, as shown in Fig. 3, revealed that almost all of the bragg peaks is consistent with those of a typical ammonium sulfate, $\left(\mathrm{NH}_{4}\right)_{2} \mathrm{SO}_{4}$, of JCPDS no. 10-343. The remaining unidentified peaks indicate very small constituents of the metal compounds. When matched with the JCPDS cards, they were found to be among the ammonium metal sulfate and metal sulfate compounds. The compounds that matched with the JCPDS cards are no. $33-090\left(\mathrm{NH}_{4}\right)_{2} \mathrm{~V}\left(\mathrm{SO}_{4}\right)_{2} \cdot 6 \mathrm{H}_{2} \mathrm{O}, \mathrm{no} .35-764$ $\left(\mathrm{NH}_{4}\right)_{2} \mathrm{Fe}\left(\mathrm{SO}_{4}\right)_{2} \cdot 6 \mathrm{H}_{2} \mathrm{O}$, no. $35-771\left(\mathrm{NH}_{4}\right)_{2} \mathrm{Mg}\left(\mathrm{SO}_{4}\right)_{2} \cdot$ $6 \mathrm{H}_{2} \mathrm{O}$, no. $22-1188 \mathrm{C}_{2} \mathrm{H}_{8} \mathrm{~N}_{4} \cdot \mathrm{NiO}_{4} \cdot 0.5 \mathrm{H}_{2} \mathrm{O}$, no. $14-179 \mathrm{VS}_{2}$,

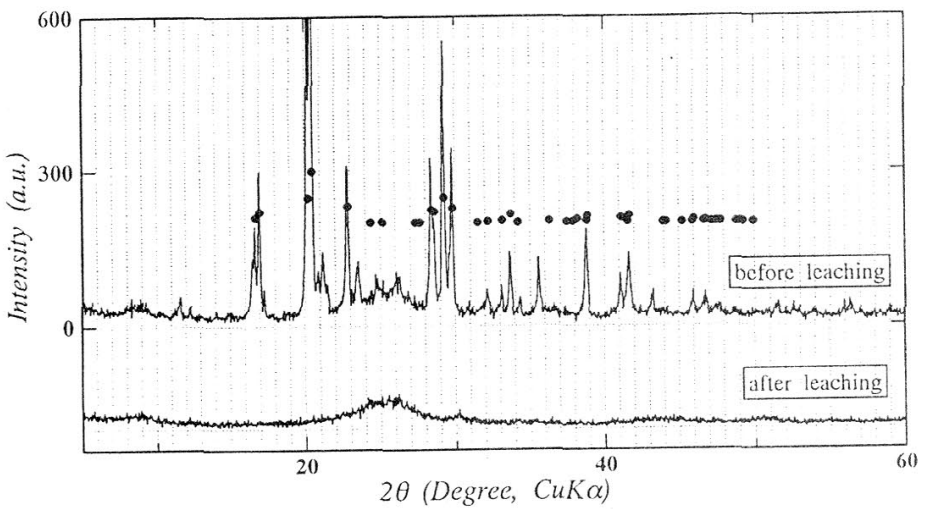

Fig. $3 \quad \mathrm{X}$-ray diffraction patterns of EP dust before and after leaching. (Circle mark assigned to $\left(\mathrm{NH}_{4}\right)_{2} \mathrm{SO}_{4}$ peaks)

and no. $1-403 \mathrm{NiSO}_{4} \cdot 7 \mathrm{H}_{2} \mathrm{O}$. The characteristic peaks of these metal compounds in the $\mathrm{X}$-ray diffraction are also overlapped by the $\left(\mathrm{NH}_{4}\right)_{2} \mathrm{SO}_{4}$ diffraction peaks. Okuwaki et al reported that vanadium pentoxide was present in their EP dust sample. For this sample, it was difficult to identify this compound from this diffraction pattern because most of the peaks coming from vanadium oxides are overlapped by the very strong peaks of ammonium sulfate. After water leaching, X-ray analysis of the residue showed only the broad diffraction band of carbon between 20 to 30 degrees.

Table 2 shows the frequency in particle size distribution obtained by screen analysis under dry condition, and metal content of $\mathrm{V}, \mathrm{Ni}$ and $\mathrm{Fe}$ of the sample particles in each screen size. The screen analysis indicated that more than $50 \%$ of the
Table 2 Particle size and metals distributions.

\begin{tabular}{rrrrrccc}
\hline \multirow{2}{*}{$\begin{array}{c}\text { screen } \\
(\text { mesh })\end{array}$} & size frequency & \multicolumn{4}{c}{ metal content $(\%)$} \\
& $(\mu \mathrm{m})$ & $($ mass\%) & ash & $\mathrm{V}$ & $\mathrm{Ni}$ & $\mathrm{Fe}$ \\
\hline+100 & 149 & 0.97 & nd & nd & nd & nd \\
$-100+200$ & 111 & 16.28 & 7.37 & 1.31 & 0.42 & 0.23 \\
$-200+300$ & 60 & 56.07 & 6.85 & 1.60 & 0.56 & 0.17 \\
$-300+400$ & 41 & 18.25 & 7.11 & 1.63 & 0.55 & 0.15 \\
-400 & 37 & 8.43 & 6.77 & 1.60 & 0.53 & 0.14 \\
\hline
\end{tabular}

EP dust sample are of the size between 200 and 300 mesh screen (ave. size $=60 \mu \mathrm{m}$ ). The chemical analysis of particles sizes larger than 200 mesh showed lower content of vanadium and nickel but higher iron content. There was no significant change in vanadium content in the particle sizes smaller than 200 mesh, while, nickel and iron content slightly decreased with decrease in particle size.

Fig. 4 shows the particle size distributions of the EP dust measured under wet condition. Since the sample in this analysis was dispersed in water, the soluble components of EP dust such as ammonium sulfate and soluble metal compounds were dissolved. Therefore, the particles visible to the analyser were mostly uncombusted carbon particles. The figure shows that the average particle size is about $34 \mu \mathrm{m}$.

SEM observation showed that the particles of uncombusted carbon were hallow and mostly spherical in shape and riddled with holes. Fig. 5 shows SEM photographs of the EP dust with EDX analysis for vanadium and sulfur. Line scanning analysis for sulfur content of the

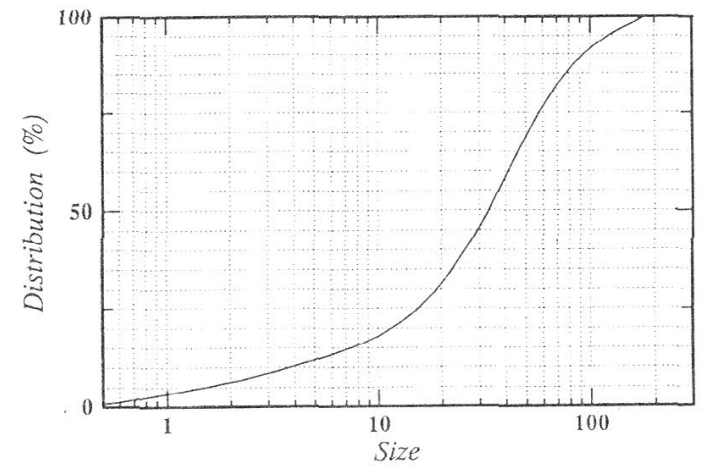

Fig. 4 Particle size distribution of EP dust.
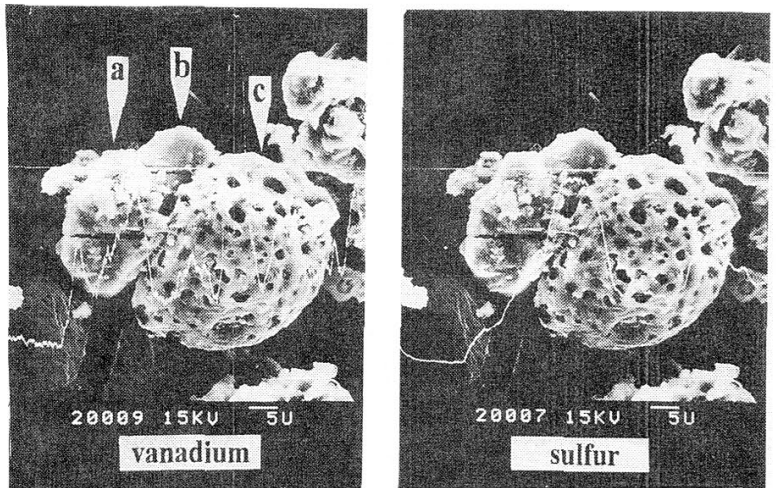

Fig. 5. SEM micrographs of EP dust with EDX analysis for vanadium and sulfur. 


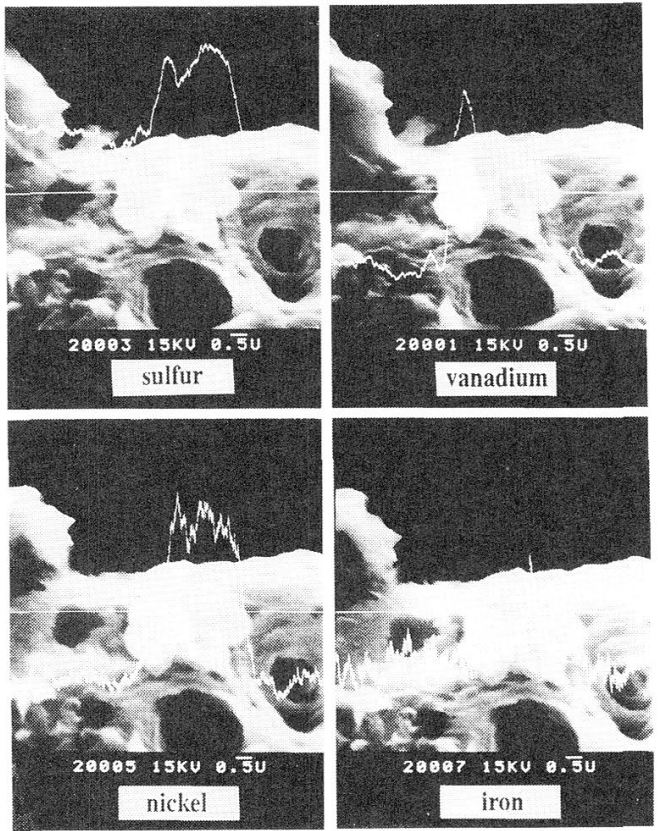

Fig. 6 SEM micrographs of EP dust with EDX analysis for sulfur, vanadium, nickel and iron.

particles marked with $a, b$ and $c$ showed that the particles a and $b$ contained higher amounts of sulfur than that of the adjacent particle $c$. The presence of higher sulfur contents on the particles $\mathrm{a}$ and b suggests that of crystalline ammonium sulfate formed by the reaction of aqueous $\mathrm{NH}_{3}$ and $\mathrm{SO}_{4}$. The particles of $\mathrm{a}$ and $\mathrm{b}$ showed to split after electron bombardment during EDX line analysis, while the larger particle $c$ that of the carbon exhibited the same but superficial. The presence of sulfur on the carbon particle as shown by EDX analysis suggests that ammonium sulfate also crystallizes on the carbon particles.

Fig. 6 shows a detailed EDX analysis on the metal components. Vanadium was observed to be in cluster of spherical shaped particles. Its particle size ranges from 0.5 to $1.5 \mu \mathrm{m}$ as measured from the photograph. Nickel was observed to be in massive irregular shaped particles. Iron is considered to be contained in the nickel rich particle which contained higher amount of sulfur than vanadium as shown in the photograph. Higher amount of sulfur in the nickel rich particle suggests its form to be that of nickel sulfate.

Fig. 7 shows the TG-DTA analysis of EP dust before and

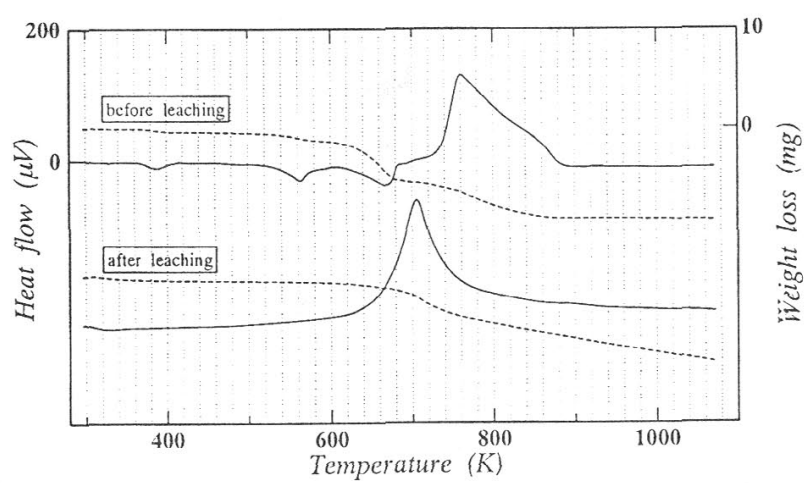

Fig. 7 TG-DTA curves of EP dust before and after leaching. after leaching by water. Three endothermic peaks and one exothermic peak appear at temperatures around 383,563,673 and $773 \mathrm{~K}$. These peaks are accompanied by-weight loss suggesting the decomposition of the sample. The first endothermic peak is due to liberation of adsorbed water and/or free sulfur. The second and third peaks appear as a result of the thermal decomposition of ammonium sulfate. The thermal decomposition reaction of ammonium sulfate was reported to proceeds according to the following reactions ${ }^{4)}$ :

$$
\begin{aligned}
& 2\left(\mathrm{NH}_{4}\right)_{2} \mathrm{SO}_{4} \longrightarrow\left(\mathrm{NH}_{4}\right)_{2} \mathrm{~S}_{2} \mathrm{O}_{7}+2 \mathrm{NH}_{3}+\mathrm{H}_{2} \mathrm{O} \quad \ldots . . \quad \text { 1) } \\
& \left.\left(\mathrm{NH}_{4}\right)_{2} \mathrm{SO}_{4} \longrightarrow \mathrm{NH}_{4} \mathrm{HSO}_{4}+\mathrm{NH}_{3} \quad \ldots \ldots \ldots \ldots \ldots \ldots . . .2\right) \\
& \left.\left(\mathrm{NH}_{4}\right)_{2} \mathrm{SO}_{4}+\mathrm{NH}_{4} \mathrm{HSO}_{4} \rightleftarrows\left(\mathrm{NH}_{4}\right)_{3} \mathrm{H}\left(\mathrm{SO}_{4}\right)_{2} \quad \cdots \cdot \cdot 3\right) \\
& \left(\mathrm{NH}_{4}\right)_{3} \mathrm{H}\left(\mathrm{SO}_{4}\right)_{2} \longrightarrow\left(\mathrm{NH}_{4}\right)_{2} \mathrm{~S}_{2} \mathrm{O}_{7}+\mathrm{NH}_{3}+\mathrm{H}_{2} \mathrm{O} \quad \cdots \quad \text { 4) } \\
& 3\left(\mathrm{NH}_{4}\right)_{2} \mathrm{~S}_{2} \mathrm{O}_{7} \longrightarrow 2 \mathrm{NH}_{3}+6 \mathrm{SO}_{2}+2 \mathrm{~N}_{2}+9 \mathrm{H}_{2} \mathrm{O} \quad \cdots \cdots \cdot \text { 5) }
\end{aligned}
$$

Combustion of the carbon particles accouts for the exothermic peak appearing at $773 \mathrm{~K}$. No significant thermograph deflection can be detected since the metal components of the sample are of relatively small quantities. According to previous works ${ }^{4)-7)}$, the thermal reaction of some metal oxides in ammonium sulfate forms ammonium metal sulfate complexes to metal sulfates below $773 \mathrm{~K}$ and over this temperature only metal oxide was found to be stable. Since the temperature in the flue is relatively high, about 473 to $773 \mathrm{~K}$ depending on firing condition, the possibility of similar rcaction by injecting ammonia is most likely to occur.

After leaching in water, only the combustion exothermic reaction of carbon was detected at around $700 \mathrm{~K}$ as seen in Figure 7. Removal of ammonium sulfate after leaching in water decreases the temperature of exothermic reaction of carbon by about $70 \mathrm{~K}$.

Flg. 8 shows the yield of metal components leached by water as a function of solid concentration of slurry. The solubility of nickel, iron and vanadium in the EP dust reveals values as high as 90, 75 and 10 percent. Nickel dissolution is high at $5 \%$ solid concentration decreasing when the solid concentration increases. Dissolution of iron increases at increasing solid concentration. While the dissolution of vanadium seems not changing with solid concentration ratio. These results show that the nickel compounds were highly soluble in water while the vanadium compounds were only slightly soluble.

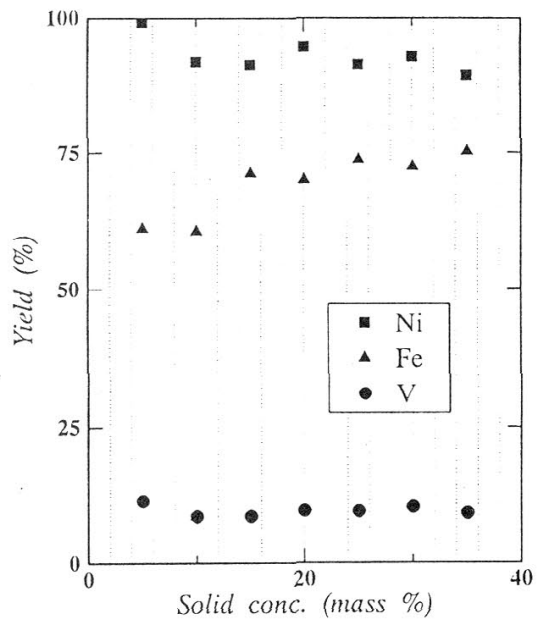

Fig. 8 Dissolution of metal components vs solid concentration. 

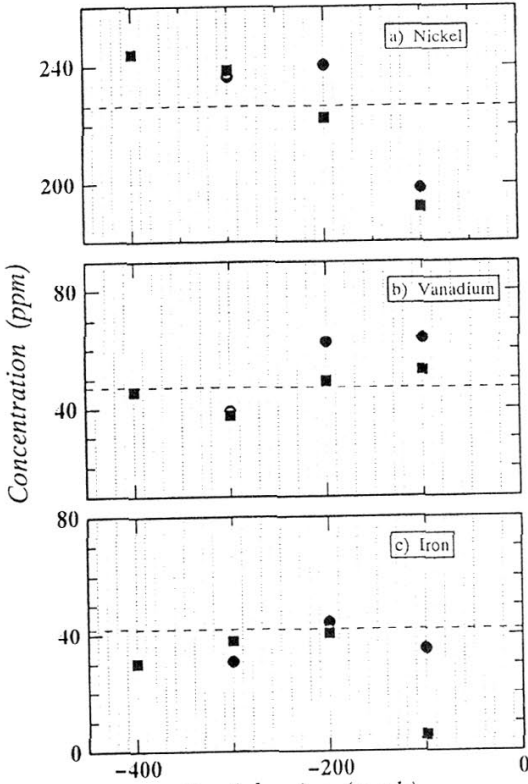

Particle size (mesh)

Fig. 9 Concentration of metals vs particle size. Classified samples marked in square and the classified samples ground to pass 400 mesh marked in circle.

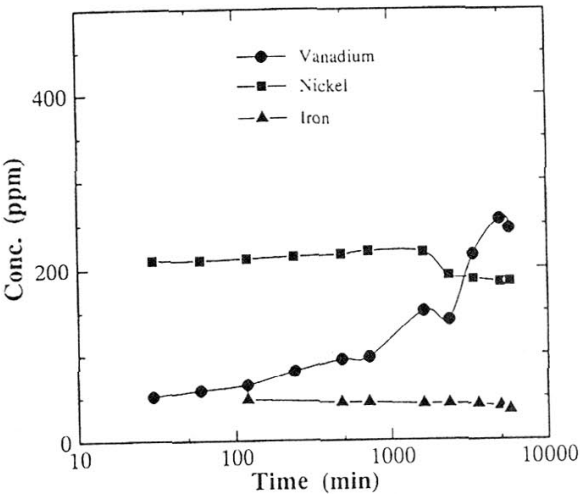

Fig. 10 Change in concentration of metals of the solution with grinding time for the specimen ground under dry condition using a tumbling ball mill.

This is due to the fact, as shown by X-ray analysis, that the nickel compounds (like ammonium nickel sulfate, nickel sulfate) detected were soluble in water while vanadium ones were slightly soluble.

Fig. 9 shows the concentrations of nickel, vanadium and iron, each leached from the classified and ground EP dust samples, respectively in distilled water without any addition of promoters. The dashed line in this figure is the concentration of soluble nickel, vanadium and iron from the original (unground and unclassified) EP dust sample. The classified specimens showed that more nickel compounds were dissolved from the finer particles than from the coarser ones. For vanadium, the coarser particles gave more and showed to increase in concentration of vanadium by grinding. The solubility of the vanadium and nickel contents in ground specimens from the classified samples $-100+200$ and $-200+300$ mesh fractions was further increased by about 15 to 25 percent. These results suggest that dissolution of the metal components can be improved by grinding the EP dust. Fig. 10 shows change in

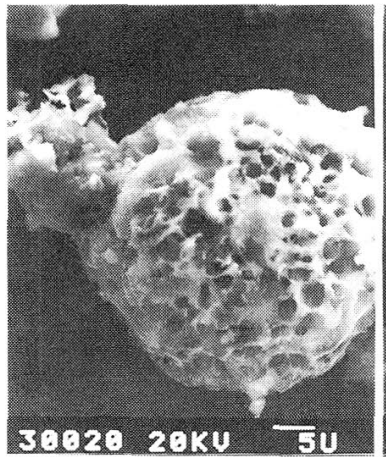

a) before leaching leaching.

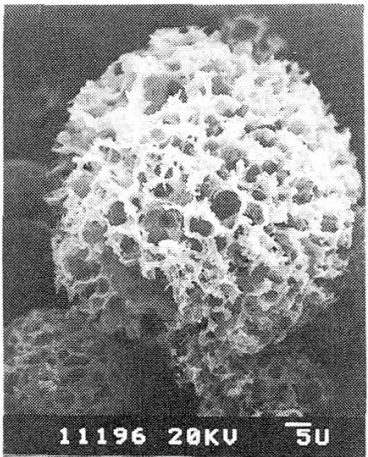

b) after leaching micrographs of EP dust particle before and after concentration of metals of the solution for the specimen ground by dry tumbling ball milling with grinding time. An upward trend in the concentration of vanadium with the progress of grinding can be observed in the figure, while no appreciable change in concentration of nickel and iron was detected. The solubility of vanadium compound in the specimen ground for 5000 minutes was higher by about 5.2 times than that for 30 minutes. This may be due to the following mechanisms: (1)formation of soluble vanadium compounds, e. g., $\mathrm{NH}_{4} \mathrm{VSO}_{4}$, by the mechanochemical reaction, (2) change in the effective surface area of the specimen available to the dissolution of metal compound caused by the size reduction and aggregation, (3) disordering of crystal structure.

The models of the particle formation and possible metal compounds in the EP dust before and after injection of ammonia solution were deduced in Table 3. Number 1 and 2 in the table indicate the location before and after addition of aqueous ammonia to the flue as shown in Fig. 1. Before leaching, the unburnt carbon is very porous and filled with the crystallizing ammonium sulfate as shown in Fig. 11 (a). The metal components and $\mathrm{SO}_{x}$ gases produced after burning the fuel with 
excess air react with each other to form the metal sulfides, sulfates and oxides compounds which remain unchanged at this point. These metal compounds, together with carbon and gases are then treated with aqueous ammonia. Subsequently, reactions take place with the particles and gases in contact with ammonia which then precipitates as ammonium sulfate, ammonium metal oxides, ammonium metal sulfides and ammonium metal sulfates. This leads to the formation of metal compounds in the flue flowing at the stream number 2 as shown in Fig. 1. The carbon remained does not react with ammonium sulfate. Ammonium sulfate and ammonium metal sulfate complexes precipitated in and on porous carbon particles. These compounds are soluble in water and it can be observed in Fig. 11 (b) showing the particles' morphology after leaching.

\section{Concluding Remarks}

This investigation was carried out from the viewpoint of standardization of characterization on EP dust for the future work. The following conclusions can be derived from the test and analyses.

1) The EP dust contains valuable and recoverable metals like vanadium, nickel, magnesium and molybdenum. Other heavy metals detected in the EP dust are iron, zinc, copper, selenium, cobalt and gallium.

2) Addition of aqueous ammonia to the flue containing the gases, metal and carbon particles causes the crystallization of ammonium sulfate. The metal compounds and the crystallizing ammonium sulfate react to form ammonium metal sulfate complexes.

3) The carbon particles are mostly spherical in shape and riddle with holes. The crystallizing ammonium sulfate is observed to be in and on the carbon particles.

4) Solubility test using distilled water, without adding any promoters, reveals that Ni $90 \%, \mathrm{Fe} 75 \%$ and V $10 \%$ can be extracted from the EP dust. Leaching test of classified specimens shows that more nickel compounds dissolve from finer grained samples and more vanadium ones from coarser grained particles. Dry grinding of the dust using a tumbling ball mill gives us the increase in solubility of vanadium compounds in water with the progress of grinding.

Acknowledgement The authors are grateful to Kashima Kita power plant for supplying the sample. One of the authors (JMF) wishes to thank the Ministry of Education and Culture of Japan for financial support provided through the Monbusho Scholarship program.

\section{References}

1) Patent No. 298489, (1987)

2) Okuwaki, A., Kimura, A., Umetsu, Y., Tozawa, K. and Okabe, T. : Ind. Eng. Chem. Res., Vol. 27, p. 1218-1222, (1988)

3) Burriesci, N., Corigliano, F., Primerano, P., Zipelli, C. and Petrera, M. : J. Chem. Soc., Faraday Trans, Vol. 80, p. 1777-1785, (1984)

4) Kiyoura, R. and Urano, K. : Ind. Eng. Chem. Proc. Des. Dev., Vol, 9, p. 489, (1970)

5) Nakamura, H., Hara, Y. and Osada, H. : J. Chem. Soc. Japan, No. 5,p. $706-$ $710,(1980)$

6) Nakamura, H., Miura, K. Hara, Y. and Osada,H. : J. Chem. Soc. Japan symposium (1979)

7) Okuwaki, A. and Chida, T.: J. Chem. Soc. Japan, No. 8, p. 1230-1242. (1980)

\section{タール・重質油混合物燃焼ダストの特性評価}

James M. Filio ${ }^{1}$ Hun S.Chung ${ }^{2}$ 梅 津 良 昭 $^{3}$ 齋藤 文 良 ${ }^{4}$

火力発電所から大量に排出される EP ダストの約 $93.5 \%$ は炭素 と硫酸アンモニゥムから構成されており, 残りの $6.5 \%$ はバナジウ ム, ニッケル, マグネシウム, モリブデン, 銅, コバルト, ガリウ 么等の有価金属の化合物から構成されている。炭素粒子はほぼ球状 で, 表面には多くの孔が認められる。硫酸アンモニウムは燃焼ガス 中に含まれる $\mathrm{SO}_{x}$ ガスとこれを固定化するために添加したアンモ 二ア水との間の反応生成物であり, 前記未燃炭素粒子や金属化合物 粒子の表面を被覆するような形で存在する。X 線回折法による分 析では, 硫酸アンモニウムは金属と反応し, 金属硫化物やアンモ二 ウム金属硫化物複合体となっている。蒸留水へのダストの溶解実験
では, ニッケル化合物は約 $90 \%$, 鉄化合物は $75 \%$, バナジゥム化 合物は約 $10 \%$ が抽出される。粒度毎に分級した試料に対する溶解 実験では, ニッヶル化合物は細粒からより溶解し, バナジゥム化合 物は粗粒からより溶解する。また, ボールミル粉砕したダストの溶 解実験では，バナジウムの収率が粉碎時間の増大とともに増加する。

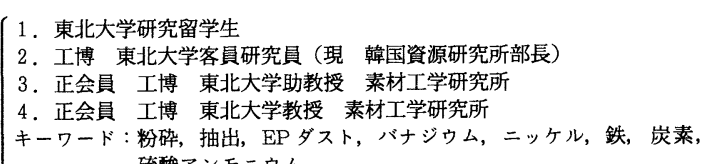

